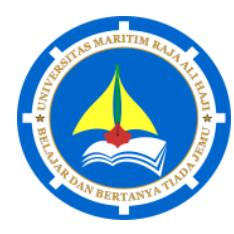

Jurnal Anugerah, 1(1) (2019)

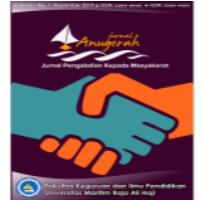

https://ojs.umrah.ac.id/index.php/anugerah

\title{
Penulisan Soal Literasi Numerasi bagi Guru SD di Kabupaten Ponorogo
}

\author{
Shofan Fiangga ${ }^{1 *}$, Siti M. Amin ${ }^{2}$, Siti Khabibah ${ }^{3}$, Rooselyna Ekawati ${ }^{4}$, Nina Rinda Prihartiwi ${ }^{5}$ \\ 1, 2, 3, 4, 5 Universitas Negeri Surabaya, Surabaya, Jawa Timur 60231, Indonesia \\ *e-mail korespondensi: shofanfiangga@unesa.ac.id \\ Pengiriman: 1 November 2019; Diterima: 21 November 2019; Publikasi: 28 November 2019
}

\begin{abstract}
Abstrak
Perubahan kurikulum bertujuan untuk memperbaiki materi dan pembelajaran. Salah satu dasar pemerintah dalam melakukan revisi tersebut adalah hasil pengukuran kompetensi dan literasi internasional sepertiProgramme for International Student Assessment (PISA). Dalam PISA, literasi numerasi menjadi salah satu poin penting pada penilaian pada kompetensi matematika. Oleh karena itu, penggunaan soal literasi sangat penting digunakan sejak siswa masih di sekolah dasar. Agar dapat mengajak siswa memahami soal-soal literasi numerasi lebih baik, guru dituntut agar mampu menyusun soal-soal literasi numerasi. Workshop penulisan soal literasi numerasi bagi guru SD di kabupaten Ponorogo ini bertujuan untuk membantu guru-guru setempat dalam meningkatkan kompetensi pedagogik guru khususnya menyusun soal literasi numerasi. Workshop penulisan soal literasi numerasi bagi guru SD di Kabupabaten Ponorogo ini dilakukan dalam tiga tahap. Tahap yang pertama adalah analisa pemahan awal guru SD terkait literasi numerasi. Tahap kedua adalah pemaparan dan sosialisasi mengenai literasi numerasi dan implementasinya di sekolah terutama pada tingkat Sekolah Dasar. Selanjutnya, tahap terakhir adalah workshop penulisan soal literasi numerasi. Soal-soal yang sudah disusun oleh peserta, akan dievaluasi dan dianalisis berdasarkan kriteria soal literasi numerasi. Selain itu, peserta mengisi angket kepuasan untuk mengetahui efektifitas dan keberhasilan workshop ini.
\end{abstract}

Kata kunci: workshop; literasi numerasi; sekolah dasar

\begin{abstract}
The change in curriculum aims to improve the quality of content and learning. One of the backgrounds of the curriculum revision is based on international tests on students' competency and literation, such as PISA. In PISA, literacy-numeracy becomes one of the essential evaluation of mathematics competency. Therefore, the use of literacy problems should be administered in the primary school class. In order to implement the literacy-numeracy problem in the class well, the teachers are required to be able to develop functional literacy problems. This workshop on writing literacy-numeracy for elementary teachers in Ponorogo City was conducted in three stages. The first stage collected the fundamental knowledge of the teachers about what they understand about literacy-numeracy. The second stage was a discussion about the literacy-numeracy and its both background and classroom implementation, especially in elementary school. The last stage was the teachers' workshop in arranging the literacy-numeracy problems. In the end, the problems developed by the teachers were analyzed based on literacy-numeracy criteria. Besides, the participants also gave feedback using a questionnaire as the information for the effectivity of the workshop.
\end{abstract}

Keywords: workshop; literacy-numeracy; elementary school

\section{Pendahuluan}

Peningkatan kualitas kurikulum yang selalu dilakukan oleh pemerintah bertujuan untuk memperbaiki materi dan pembelajaran pada satuan pendidikan yang ada. Salah satu menjadi dasar pemerintah dalam melakukan revisi tersebut adalah hasil pengukuran kompetensi dan literasi internasional seperti PISA. PISA merupakan singkatan dari Programme for International Student Assessment. PISA merupakan sebuah proyek dari 
Organisation for Economic Co-operation and Development (OECD) yang dirancang untuk mengevaluasi hasil pendidikan dalam hal kemampuan siswa yang berumur 15 tahun, atau untuk tahap pendidikan di Indonesia adalah anak di tingkat Sekolah Menengah Pertama (SMP), di bidang matematika, membaca, dan sains. Berdasarkan hasil penilaian tersebut, dapat dilihat bahwa literasi menjadi bagian penting pada pengembangan kurikulum 2013 di mana hasil dari PISA sendiri untuk literasi numerasi siswa SMP di Indonesia sangat rendah.

Hasil PISA untuk bidang Matematika tahun 2015 menempatkan Indonesia pada peringkat 45 dari 50 negara yang mengikuti PISA (Rahmawati, 2016). Lebih jauh lagi, hasil pencapaian siswa SMP untuk PISA di Jawa Timur menunjukkan mesih rendahnya kemampuan mereka dalam mengerjakan soal-soal yang membutuhkan penalaran matematis seperti PISA (Jayanti, 2017). Berdasarkan informasi tersebut maka guruguru perlu membiasakan siswanya dalam menyelesaikan soal yang bertemakan literasi numerasi tersebut.

Menurut OECD, literasi matematika adalah kapasitas siswa untuk merumuskan, menerapkan, dan menafsirkan matematika dalam berbagai konteks (PISA, 2016). Pengertian Literasi numerasi sendiri adalah pengetahuan dan kecakapan untuk (a) menggunakan berbagai macam angka dan simbol-simbol yang terkait dengan matematika dasar untuk memecahkan masalah praktis dalam berbagai macam konteks kehidupan sehari-hari dan (b) menganalisis informasi yang ditampilkan dalam berbagai bentuk (grafik, tabel, bagan, dsb.) lalu menggunakan interpretasi hasil analisis tersebut untuk memprediksi dan mengambil keputusan (Kemdikbud, 2017). Literasi numerasi juga menuntut siswa untuk mengkomunikasikan dan menjelaskan fenomena yang dihadapinya dengan konsep matematika (Prenzel, Blum, \& Klieme, 2015).

Alasan utama yang menyebabkan siswa masih belum dapat menyelesaikan permasalahan berbasis literasi numerasi adalah guru yang belum membiasakan siswa dengan soal-soal berbasis literasi. Hal ini disebabkan masih banyak guru yang masih belum mampu menyusun soal literasi numerasi terutama untuk guru-guru di tingkat sekolah dasar agar siswa menjadi lebih terbiasa untuk menyelesaiakn soal-soal non-rutin tersebut. Guru cenderung membuat soal rutin yang tertutup dan dapat langsung diselesaikan dengan penggunaan suatu rumus (Kartikasari, Kusmayadi, \& Usodo, 2016). Oleh karena itu fokus peningkatan kualitas guru dalam meningkatkan kemampuan siswa dalam literasi numerasi sangat penting.

Di tingkat SD, kurikulum 2013 mensyaratkan tematik di setiap pembelajarannya(Kemendikbud, 2016).Penerapan tematik di tingkat SD, ternyata belum bisa menjamin pengalaman siswa dalam menyelesaikan soal literasi numerasi karena terkait dengan kratifitas siswa. Beberapa penelitian menemukan bahwa penggunaan tematik dalam peningkatan kreatifitas masih terbatas (Arista, Marzuki, \& Krenadi, 2014; Setiana, 2016). Beberapa kegiatan yang sudah dilakukan sebelumnya masih belum fokus pada penanganan literasi numerasi (Mukharomah, 2018; Suyitno, 2013). Hal ini menyebabkan guru SD yang seharusnya menjadi pintu pertama pengenalan siswa terhadap pemahaman literasi numerasi tidak maksimal. Kenyataanya, seperti yang diungkapkan oleh Kartikasai dkk bahwa pengalaman siswa dalam menyelesaikan soal hanya terbatas pada soal rutin yang sebagian besar hanya memiliki satu jawaban benar. Hal ini membatasi kreatifitas siswa yang pada dasarnya sangat berkembang di tingkat SD.

Berdasarkan hasil observasi di Dinas Pendidikan Dasar Kabupaten Ponorogo diperoleh data: (1) belum semua guru sekolah dasar yang mengajar di sekolah tersebut menggunakan soal literasi numerasi dalam pembelajarannya dan (2) belum semua guru yang mengajar di sekolah tersebut mendapat kesempatan menyusun soal literasi numerasi sendiri yang berkualitas. Dengan demikian, pihak Dinas pendidikan Dasar dan Sekolah (Kepala Sekolah) mengusulkan kepada Tim kami untuk memberi pelatihan penyusunan soal literasi numerasi untuk guru-guru SD di kabuparen Ponorogo.

Berdasarkan analisis situasi tersebut, rumusan masalah pada kegiatan pengabdian pada masyarakat ini adalah: (1) bagaimanakah kemampuan awal peserta dalam penulisan soal literasi numerasi?(2) apakah peserta dapat menyusun soal literasi numerasi untuk tingkat sekolah dasar? dan (3) bagaimana respon peserta Workshop penulisan soal literasi numerasi bagi guru SD di Kabupaten Ponorogo? 


\begin{abstract}
Metode
Program PkM yang dilaksanakan pada tahun 2019 di Kabupaten Ponorogo ini meliputi: (1) paparan mengenai PISA dan literasi numerasi tingkat SD. Pada kegiatan ini dipaparkan dan diberi contoh soal-soal berbasis literasi numerasi dalam pembelajaran matematika dan (2) workshop penulisan soal literasi numerasi bagi guru SD kelas 4-6 di kabupaten Ponorogo. Pada kegiatan ini, guru dibagi dalam kelompok-kelompok kecil (2-3 orang) untuk memilih suatu konteks dan mengembangkan soal literasi numerasi berdasarkan konteks yang sudah dipilih. Sasaran pada PkM kali ini adalah guru-guru Sekolah Dasar di Kabupaten Ponorogo. Keterlibatan Kepala Sekolah dan kelompok MGMP Guru SD di Kabupaten Ponorogo diharapkan dapat mengawal keberlanjutan penerapan materi yang diperoleh pada kegiatan pelatihan ini.

Metode yang digunakan untuk mencapai tujuan kegiatan ini adalah dengan ceramah dan workshop tentang penulisan soal literasi numerasi bagi guru SD yang melalui tahapan berikut ini. Pertama, pemaparan penulisan soal literasi numerasi bagi guru SD di kabupaten Ponorogo. Pada tahap ini, narasumber menyampaikan latar belakang terkait literasi numerasi serta pembahasan beberapa soal yang bisa menjadi referensi dalam menyusun soal literasi numerasi pada pembelajaran matematika. Kedua, workshop penulisan soal literasi numerasi bagi guru SD di kabupaten Ponorogo. Pada kegiatan kali ini, peserta dengan dibimbing oleh narasumber mengembangkan soal-soal literasi numerasi yang bisa diterapkan dalam materi matematika tertentu di kelas. Terakhir, evaluasi kegiatan workshop penulisan soal literasi numerasi menggunakan angket respon untuk mengetahui kemampuan awal, hasil pelatihan, dan respon peserta terhadap kegiatan pelatihan. Dengan demikian, berikut detail evaluasi yang dilakukan pada PkM: (1) memberikan angket kepada peserta sebelum workshop penulisan soal literasi numerasi bagi guru SD di kabupaten Ponorogo, (2) menganalisis soal yang telah dikembangkan oleh peserta workshop, dan (3) memberikan angket setelah keseluruhan kegiatan berakhir.
\end{abstract}

\title{
Hasil dan Pembahasan
}

Kegiatan pelatihan ini dilakukan selama 6 (enam) bulan, yaitu bulan Mei 2019 sampai dengan November 2019, bertempat di gedung SD Muhammadiyah 2 Ponorogo. Adapun hasil yang diperoleh dapat dituangkan dalam bentuk hasil kegiatan pada setiap tahap pelaksanaan sebagai berikut.

Pertama-tama, sosialisasi dilakukan pada bulan Mei 2019 dalam bentuk rapat koordinasi dengan mengundang pihak Dinas pendidikan Dasar dan Sekolah (Kepala Sekolah) berkenaan dengan kegiatan PKM yang akan dilaksanakan. Selanjutnya, berdasarkan hasil identifikasi, hasil analisis permasalahan yang ada, dan hasil analisis kebutuhan, selanjutnya disusun program pelatihan. Pelaksanaan pelatihan dilakukan selama 1 (satu) kali tatap muka, dengan mengundang guru-guru SD di kabuparen Ponorogo. Kemudian, Seminggu sebelum pelaksanaan program calon peserta pelatihan yang sudah mendaftar diminta mengisi angket pemahaman awal terkait linterasi numerasi. Angket ini bertujuan untuk mengetahui kemampuan awal guruguru SD di Kabupaten Ponorogo terkait Literasi numerasi. Pengalaman mengajar guru yang mengikuti pelatihan ini sangat bervariasi namun masih didominasi oleh 10-20 tahun dan 5-10 tahun (lihat gambar 1). Akan tetapi, $100 \%$ peserta menyatakan bahwa belum pernah mengikuti pelatihan terkait literasi numerasi. 


\section{Pengalaman Mengajar}

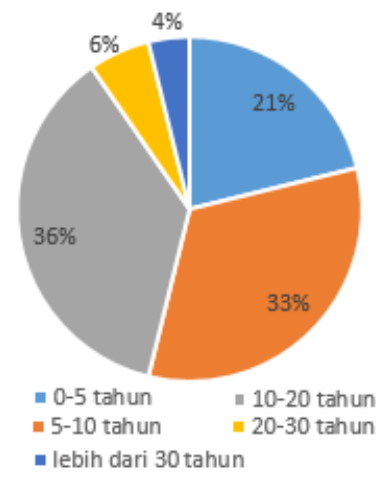

Gambar 1, Diagram pengalaman mengajar peserta workshop

Selanjutnya pertanyaan terkait pemahaman literasi numerasi mendapatkan hasil bahwa hampir semua peserta tidak memahami apa itu literasi numerasi. Akan tetapi, ada 4 peserta yang mampu mendefinisikan literasi numerasi menggunakan kata-katanya sendiri dengan tepat. Berikut respon pemahaman awal peserta dapat dilihat pada tabel 1 . Respon yang diberi warna merah adalah definisi literasi numerasi yang mendekati pengertian numerasi numerasi yang sebenarnya.

Tabel 1.

Pemahaman awal peserta workshop literasi numerasi

2. Apa yang Anda ketahui tentang soal literasi numerasi? Jelaskan dengan kata-kata anda sendiri!

- Pengetahuan dalam menggunakan angka

- Soal yang berkaitan dengan angka

- Kemampuan dalam menggunakan angka untuk memecahkan masalah sehari-hari

- Soal yang berdasarkan prinsip literasi dengan menggabungkan teknik membaca, menulis, mendengar, dll

- Literasi itu pelajaran tambahan sebelum KBM dimulai

- $\quad$ soal-soal matematika yang mengaitkan dengan masalah dalam kehidupan sehari-hari siswa sehingga mudah untuk dipahami

- Pengetahuan untukmenggunakan berbagai macam angka dan simbol yang terkait dengan matematika dasar guna memecahkan masalah dan menganalisis informasi yang ditampilkan dalam bentuk grafik atau tabel

- Pengetahuan dan kecakapan menggunakan angka dan simbol-simbol matematika

- Soal cerita yang berkaitan dengan angka.

- Kemampuan untuk mengaplikasikan konsep bilangan dan keterampilan operasi hitung di dalam kehidupan sehari-hari misalnya, di rumah, pekerjaan, dan partisipasi dalam kehidupan sehari-hari

- Tata cara penulisan nomer atau angka pada karya ilmiah/non ilmiah

\section{Pelaksanaan Workshop}

Pada kegiatan workshop, terdiri dari paparan narasumber dan diskusi pengembangan soal yang diakhiri dengan evaluasi.Pembukaan dilaksanakn pukul 8.00 dimulai dengan pembukaan oleh MC dari guru SD Muhammadiyah Ponorogo diikuti sambutan oleh Kepala Sekolah SD Muhammdiyah Ponorogo Triono Ali Mustofa, M.Pd.I. Selanjutnya, Pembukaan oleh Sekretaris Jurusan Matematika FMIPA Unesa, Rooselyna Ekawati, M.Sc.,Ph.D. 


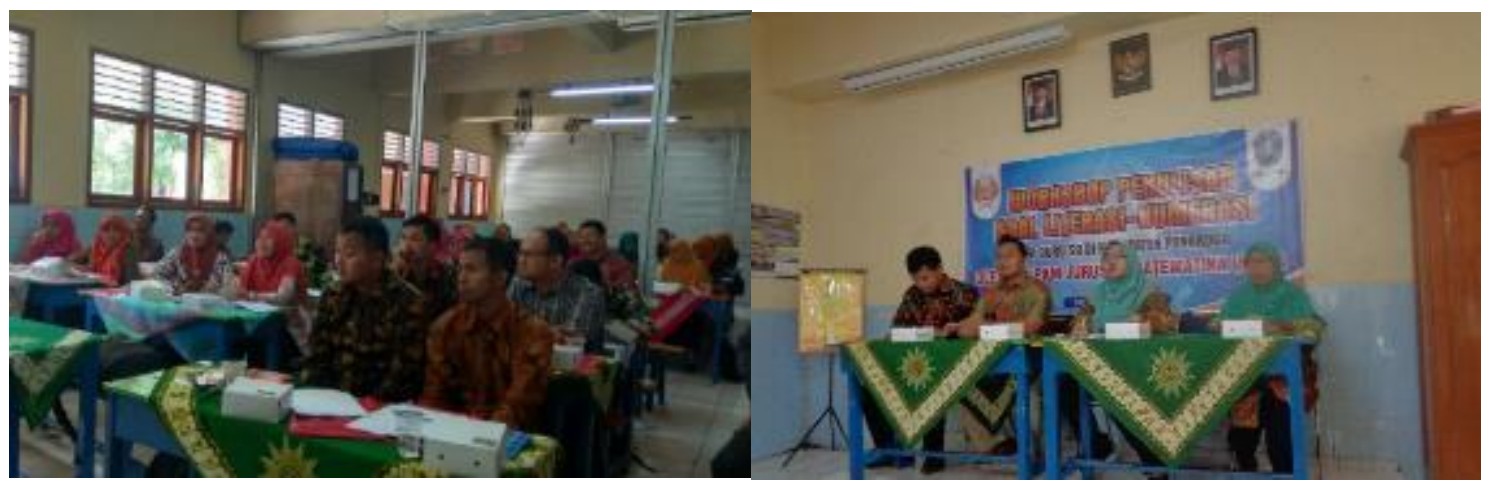

Gambar 2. Pembukaan kegiatan PKM

Pemaparan Materi disampaikan terlebih dahulu oleh Shofan Fiangga, S.Pd, M.Sc dan Rooselyna Ekawati, M.Sc., Ph.D. terkait teori mengenai pengembangan soal literasi dan juga latar belakang kenapa soal literasi numerasi sangat penting untuk disajikan kepada siswa SD. Selanjutnya pemaparan contoh soal dan pengemabnagn disajikan oleh Prof. Dr. Siti M. Amin, M.Pd.dan Dr. Siti Khabibah, M.Pd.

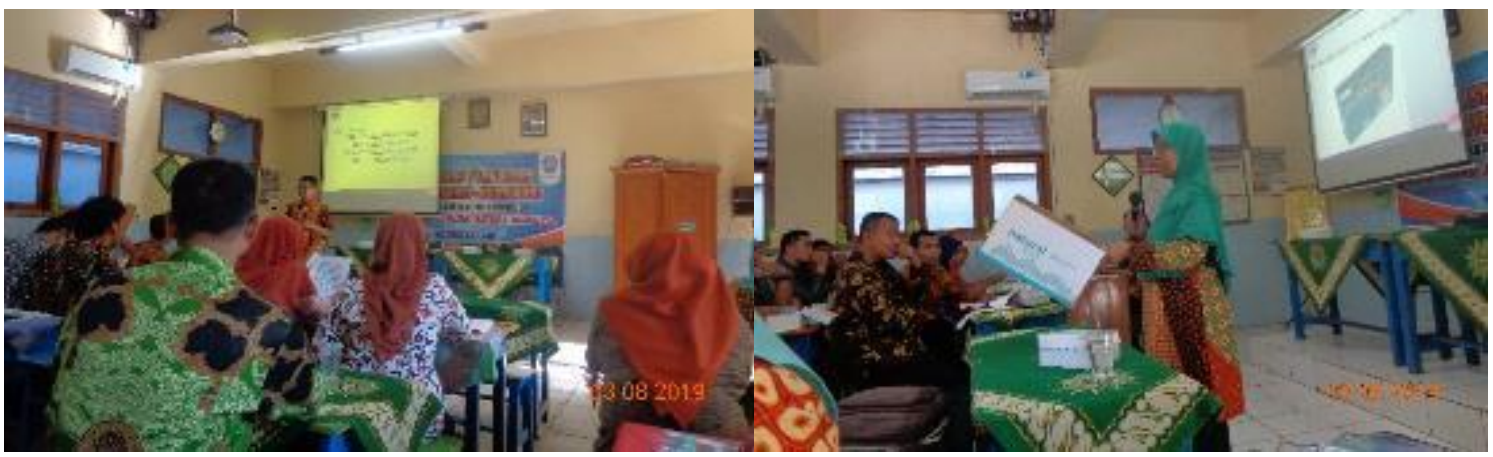

Gambar 3, Sesi pembahasan contoh soal literasi numerasi

Sesi selanjutnya dilanjutkan dengan kegiatan penyusunan dan pengembangan soal literasi numerasi yang dilakukan oleh peserta dan dibimbing oleh keempat narasumber.
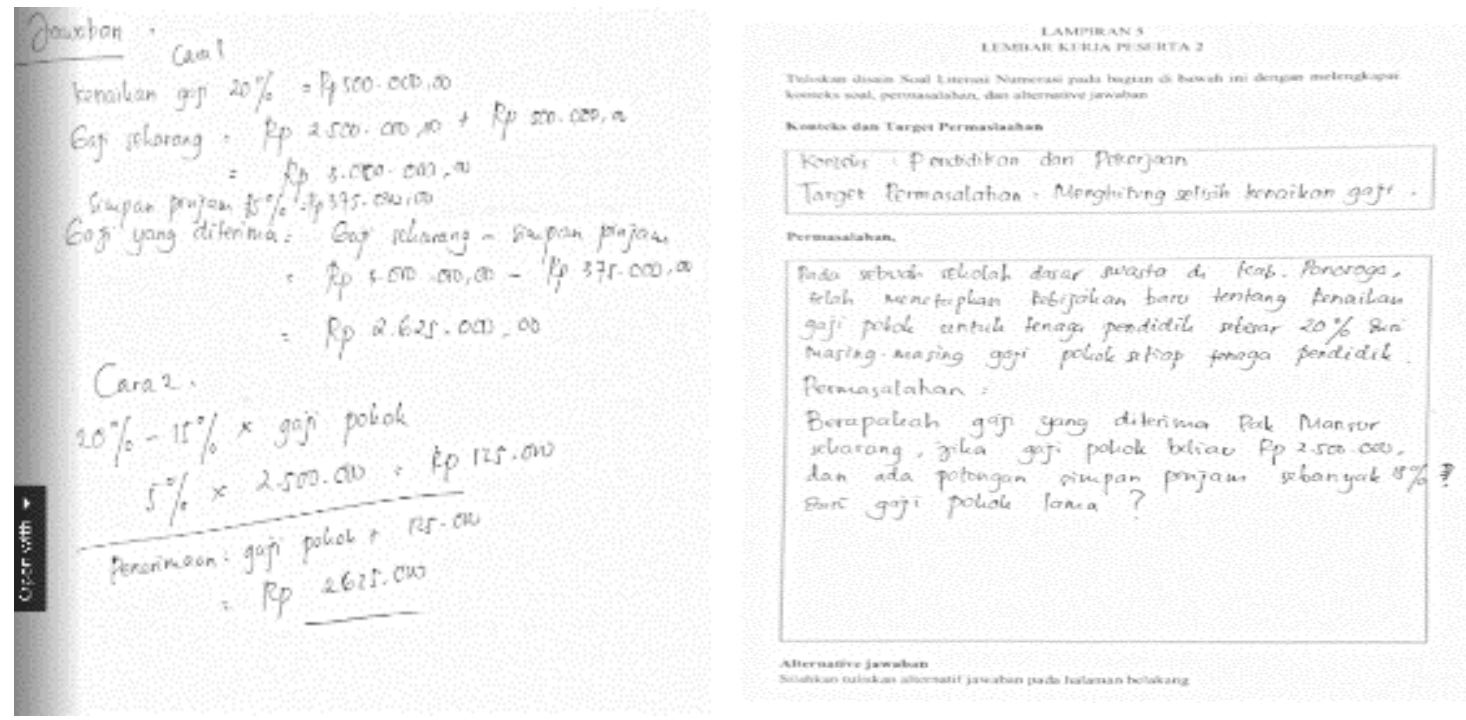

Gambar 4. Soal literasi peserta yang dibahas pada sesi presentasi 
Berdasarkan soal yang berhasil dihimpun, soal-soal yang dikembangkan membutuhkan pengetahuan siswa terkait matematika untuk digunakan dalam kehidupan sehari-hari. Namun, karena batasan pelatihan kali ini hanya ada pada literasi numerasi, harusnya soal-soal yang dikembangkan peserta mengarah kepada perhitungan dan penggunaan bilangan. Kenyataannya, beberapa soal yang sudah dikembangkan peserta sudah mengarah membutuhkan konsep matematika selain bilangan dan perhitungan yang lebih dikenal sebagai literasi matematika. 38 dari 51 soal yang dikembangkan guru memiliki jawaban atau cara penyelesaian yang tidak tunggal. Hal ini memang disengaja karena peserta bisa lebih leluasa mengembangkan soal yang terkait pemahaman matematika dengan catatan konsep matematika yang digunakan masih bisa dijangkau oleh siswa di tingkat sekolah dasar. Walaupun demikian, soal-soal yang dikembangkan sudah layak untuk digunakan dalam pembelajaran matematika di tingkat SD.

Diakhir workshop, peserta melakukan refleksi terkait workshop secara lisan maupun online melalui website. Peserta memberikan refleksi mengenai workshop dan pemahamannya sehingga.Berikut beberapa rangkuman hasil angket respon peserta terkait pemahaman peserta.

Tabel 2.

Kesan peserta terhadap workshop literasi numerasi

1. Setelah menjalani rangkaian kegiatan workshop ini , apa yang membedakan kegiatan workshop ini dengan kegiatan workshop yang pernah Bapak/Ibu ikuti sebelumnya?

- Lebih menarik dan memahami arti dari pelajaran matematika. Bahwa ilmu matematika bukan ilmu pasti dengan 1 jawaban saja.

- Workshop ini membuka mata hati kita bahwa setiap orang/siswa berhak untuk menyelesaikan permasalahan dengan cara mereka masing-masing. Dan kita sebaiknya untuk tidak langsung menyalahkan mereka.

- Workshop sekarang lebih kontekstual

- Sesuatu yang baru di workshop yang pernah saya jalani karena tentang literasi matematika

- Kontekstual, menghargai berbagai pendapat, merubah mindset bahwa semua harus sesuai pikiran guru, dan mengajarkan cara menulis soal yg bertumpu pada proses dan penalaran anak.

- Cara menyajikan materi lebih jelas

- Workshop kali ini lebih membangkitkan semangat dalam mengajar matematika

- Lebih menyenangkan, lebih menambah wawasan dari yang saya belum tahu menjadi tahu, dan tentunya menjadi bersemangat belajar lagi

- Lebih menyenangkan, biasanya kl workshop Matetika yg lain, kita dituntut agak serius, dan endingnya bosan.

- Kegiatan workshop ini membuka wawasan kita tentang bagaimana kita menghadapi siswa dalam menjawab soal-soal yang memungkinkan prosesnya lebih dari satu jalan. selain itu, guru juga diberi pengetahuan betapa penting memberikan latihan soal penalaran

Berdasarkan data pada tabel 2, dapat disimpulkan bahwa seluruh peserta mampu mengikuti workshop dengan baik. Akan tetapi, dari respon tersebut, bisa dilihat jika peserta masih menganggap materi yang disampaikan adalah literasi matematika. Dimana, sebenarnya, literasi numerasi hanya terkait pada aplikasi simbol dan bilangan serta perhitungannya pada konteks sehari-hari. Selanjutnya, peserta diminta memberikan pendapatnya terkait kebermanfaatan dari kegiatan ini. Hasil respon peserta dapat dilihat pada table 3 berikut ini. 
Tabel 3.

Pemahaman peserta setelah menjalani workshop literasi numerasi

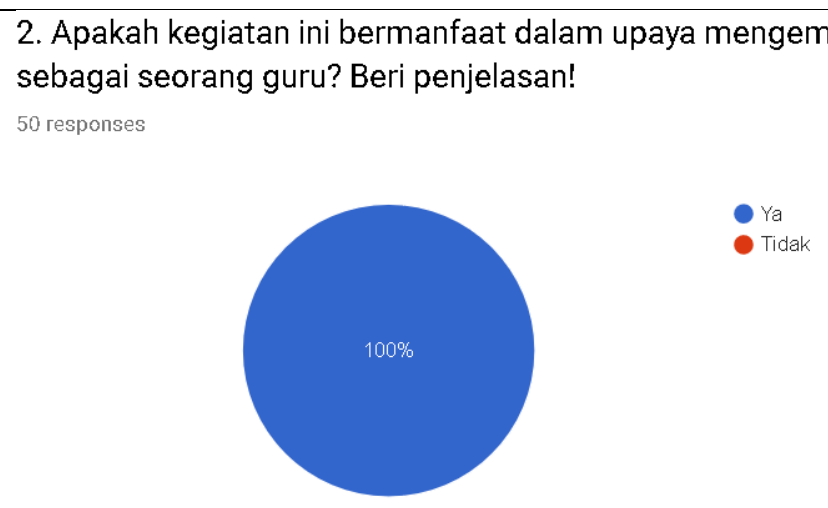

Beri penjelasan!

- Menjadi guru bukan hal yang harus selalu menyalahkan jawaban siswa. Krena siswa mempunyai alasan sendiri dr jawaban yang di tulis.

- Ya karena kita bisa lebih menghargai satu sama lain. Dan lebih bisa mengembangkan soal matematika menjadi lebih menarik lagi.

- Bisa lebih mengembangkan terutama saat membuat soal/ menjelaskan ke siswa

- Bermanfaat,karena menambah wawasan saya dan menambah modal saya sebagai guru dalam melaksanakan literasi

- Diperlukan dalam merubah mindset dan pola guru dalam mengajar

- Sesuai dengan kegiatan pembelajaran bahwa kita selaku pengajar tidak lepas dari soal

- Karena dengan workshop ini kita menjadi tahu, apa yang salah atau langkah kita dapat di revisi sehingga menjadi lebih baik dan tentunya benar

- Sangat mwmbantu utuk kami sebagai guru.lebih maju

- tentu dong. Guru harus mengikuti perkembangan dan mau berkembang, tidak saklek pada pengajaran sebelumnya yang seharusnya itu perlu diupdate (jangan dihilangkan langsung) hohoho

- Untuk mengetahui bagaimana menyikapi suatu pembahasan soal

Berdasarkan data pada tabel 3, dapat disimpulkan bahwa seluruh peserta mendapatkan manfaat yang berhubungan dengan pembelajarannya di kelas dari workshop. Sebagian besar peserta menyadari bahwa pembelajaran yang baik perlu melibatkan keaktifan guru dalam mengikuti perkembangan jaman dan berusaha memahami proses berfikir siswa lebih dalam. Hal ini sangat penting karena seringkali guru terlalu dini menyalahkan jawaban siswanya tanpa mengetahui alasan dari siswa tersebut.

Selain itu, angket peserta juga mengukur respon peserta terhadap pelaksanaan kegiatan workshop. Berikut ini rekapitulasi respon peserta terhadap kegiatan. Untuk setiap indikator peserta memilih skala dari $1-5$.

Tabel 4.

Respon peserta terhadap kegiatan workshop

\begin{tabular}{llcccccc}
\hline No & Indikator & $\begin{array}{c}\text { (Sangat } \\
\text { Baik) } \\
\mathbf{d = 5}\end{array}$ & $\begin{array}{c}\text { (Baik) } \\
\mathbf{d = 4}\end{array}$ & $\begin{array}{c}\text { (Cukup) } \\
\mathbf{d = 3}\end{array}$ & $\begin{array}{c}\text { (Tidak } \\
\text { Baik) } \\
\mathbf{d = 2}\end{array}$ & $\begin{array}{c}\text { (Sangat } \\
\text { Tidak } \\
\text { Baik) } \\
\mathbf{d = 1}\end{array}$ & $\begin{array}{c}\text { Bobot } \\
\frac{\sum \boldsymbol{f} . \boldsymbol{d}}{\boldsymbol{n}} \\
\boldsymbol{n}=\mathbf{5 1}\end{array}$ \\
\hline 1 & $\begin{array}{l}\text { Kesesuaian penyajian bahan / materi } \\
\text { dengan workshop }\end{array}$ & 25 & 26 & 0 & 0 & 0 & 4.50 \\
\hline
\end{tabular}


JURNAL ANUGERAH. November 2019; I(1): 9 - 18

\begin{tabular}{|c|c|c|c|c|c|c|c|}
\hline 2 & Organisasi Materi & 15 & 31 & 5 & 0 & 0 & 4.20 \\
\hline 3 & Pencapaian tujuan workshop & 24 & 26 & 1 & 0 & 0 & 4.46 \\
\hline 4 & Metode workshop yang digunakan & 23 & 27 & 1 & 0 & 0 & 4.44 \\
\hline 5 & $\begin{array}{l}\text { Kebermanfaatan Materi Workshop } \\
\text { terhadap Pembelajaran di Kelas }\end{array}$ & 34 & 17 & 0 & 0 & 0 & 4.67 \\
\hline 6 & Kemampuan Membawakan Materi & 32 & 18 & 1 & 0 & 0 & 4.61 \\
\hline 7 & $\begin{array}{l}\text { Alokasi Waktu Penyampaian antar } \\
\text { Materi }\end{array}$ & 22 & 27 & 2 & 0 & 0 & 4.40 \\
\hline 8 & $\begin{array}{l}\text { Responsif terhadap pernyataan atau } \\
\text { usulan peserta }\end{array}$ & 32 & 18 & 1 & 0 & 0 & 4.61 \\
\hline 9 & Penguasaan kelas yang interaktif & 26 & 24 & 1 & 0 & 0 & 4.50 \\
\hline 10 & Pelaksanaan Diskusi yang Efektif & 20 & 27 & 4 & 0 & 0 & 4.32 \\
\hline 11 & $\begin{array}{l}\text { Kesesuaian Jawaban Pemateri terhadap } \\
\text { pertanyaan }\end{array}$ & 24 & 26 & 1 & 0 & 0 & 4.46 \\
\hline 12 & $\begin{array}{l}\text { Kesesuaian Waktu Penyelenggaraan } \\
\text { Workshop }\end{array}$ & 24 & 24 & 3 & 0 & 0 & 4.42 \\
\hline 13 & Fasilitas Pelatihan bagi Peserta & 29 & 20 & 2 & 0 & 0 & 4.53 \\
\hline 14 & $\begin{array}{l}\text { Kualitas tugas sudah sesuai dan } \\
\text { mendukung } 32 \text { jam pelaksanaan tatap } \\
\text { muka }\end{array}$ & 24 & 24 & 3 & 0 & 0 & 4.42 \\
\hline 15 & Kepuasan Layanan Panitia Pelaksana & 29 & 21 & 0 & 1 & 0 & 4.53 \\
\hline 16 & Keramahan Panitia Pelaksana & 37 & 14 & 0 & 0 & 0 & 4.73 \\
\hline \multirow{2}{*}{\multicolumn{2}{|c|}{ Total }} & 420 & 370 & 25 & 1 & 0 & \\
\hline & & $51.47 \%$ & $45.34 \%$ & $3.06 \%$ & $0.12 \%$ & $0.00 \%$ & \\
\hline
\end{tabular}

Hasil respon peserta menunjukkan bahwa dari 51 responden yang mengisi setiap kategori memiliki lebih dari $90 \%$ respon yang menyatakan minimal baik. Terdapat 3 kategori yang 100\% dari respon peserta berkriteria minimal baik yatu kategori kesesuaian penyajian bahan / materi dengan workshop, Kebermanfaatan Materi Workshop terhadap Pembelajaran di Kelas, dan Keramahan Panitia Pelaksana. Sedangkan pada kategori pengorganisasian materi mendapatkan persentase minimal baik palig rendah yaitu 90\%. Secara keseluruhan lebih dari $96 \%$ peserta mengkategorikan pelaksanakan pelatihan ini minimal baik. Untuk detailnya, 51.47\% menyatakan pelaksanaan pelatihan sangat baik dan $45.34 \%$ menyatakan baik.

Pemahaman peserta terkait penulisan soal literasi sudah berubah terkait penggunaan soal rutin dalam pembelajaran di kelas. Hal ini bisa dilihat dari soal yang dikembangkan oleh peserta selama workshop sudah memberi kesempatan siswa dalam mengajukan ide penyelesaiannya sendiri tanpa harus terikat oleh jawaban guru. Hal inilah yang menjadi pokok permasalahan sesuai yang disampaikan Kartikasari dkk (Kartikasari et al., 2016). Selain itu, pada pelatihan ini lebih fokus pada pemahaman guru SD terkait literasi numerasi, berbeda dengan PkM sejenis yang cenderung fokus pada intervensi teknologi (Wardono, Waluya, Kartono, Mulyono, \& Mariani, 2018). Sebagian besar guru SD di kabupaten Ponorogo yang tidak memiliki latar belakang keilmuan matematika membuat pendekatan materi dan konteks melalui paparan literasi numerasi menjadi lebih efektif dan bermanfaat bagi peserta workshop. Walaupun kajian terkait hubungan latar belakang keilmuan dengan kemampuan mengembangkan soal literasi numerasi perlu dikaji lebih lanjut lagi.

\section{Kesimpulan}

Berdasarkan hasil dan pembahasan yang disajikan pada bab sebelumnya, untuk pelaksanaan kegiatan PKM ini dapat dikemukakan simpulan sebagai berikut. Secara umum, para peserta memberi respons positif terhadap pelaksanaan kegiatan "Workshop Penulisan Soal Literasi numerasi bagi Guru SD di Kabupaten 
Ponorogo". Kesimpulan yang dapat diperoleh adalah sebagai berikut (1) $100 \%$ peserta mengaku belum pernah mendapat pelatihan literasi numerasi. Akan tetapi, sebanyak 4 peserta (8\%) mampu mendefinisikan literasi numerasi mendekati pemahaman sebenarnya. (2) Berdasarkan soal yang dikembangakn peserta, peserta mampu membuat soal yang membutuhkan pengetahuan siswa terkait matematika untuk digunakan dalam kehidupan sehari-hari, akan tetapi, karena batasan pelatihan kali ini hanya ada pada literasi numerasi, harusnya soal-soal yang dikembangkan peserta mengarah kepada perhitungan dan penggunaan bilangan. Kenyataannya, beberapa soal sudah mengarah membutuhkan konsep matematika selain bilangan dan perhitungan yang lebih dikenal sebagai literasi matematika (3) terkait respon peserta setelha mengikuti pelatihan ini, dengan rata-rata sekitar $96 \%$ peserta memberikan respon minimal baik terhadap pelaksanaan PKM ini.

\section{Saran}

Secara umum, dalam rangka peningkatan profesionalitas guru, yang khususnya kemampuan guru dalam pengembangan soal literasi numerasi, pada masa mendatang, kegiatan pemantapan dan workshop semacam ini hendaknya dapat mengakomodasi harapan peserta, yang dapat dikategorisasikan sebagai berikut: (1) sudah Bagus 26\%, (2) Perlu ditingkatkan kualitas materi dan soal 40\%, (3) Perlu ditambah frekuensi pelatihan 14\%, dan (4) Perlu tindak lanjut 20\%. Selain saran dari peserta workshop, berdasarkan refleksi pelatihan, pelaksanaan pelatihan harus lebih konsisten dalam pembatasan materi agar luaran yang diharapkan mampu dihasilkan oleh peserta tidak terlalu luas. Selain itu, perlu dilakukan keajian terkait latar belakang keilmuan dan pemahaman mengenai literasi numerasi terkait data awal sebagai persiapan dalam mengembangkan program pelatihan sejenis.

\section{Ucapan Terimakasih}

Terima kasih kepada FMIPA Unesa atas dukungan finansial dan SD Muhammadiyah Ponorogo atas dukungannya terkait fasilitas tempat pelatihan.

\section{Referensi}

Arista, F., Marzuki, \& Krenadi, H. (2014). Dampak pembelajaran tematik terhadap perolehan belajar peserta didik di sekolah dasar. FKIP Untan, 1-10.

Jayanti Ardianika Putri. (2017). Kemampuan penalaran matematis siswa SMP kelas VIII dalam menyelesaikan soal PISA matematika di Kota Kediri. Simki-Techsain, 01(02), 2017.

Kartikasari, M., Kusmayadi, T. A., \& Usodo, B. (2016). Kreativitas guru sma dalam menyusun soal renah kognitif ditinjau dari pengalaman kerja. Prosiding Seminar Matematika Dan Pendidikan Matematika, (November), 431-442.

Kemendikbud. Permendikbud No. 21 tahun 2016 tentang Standar Isi Pendidikan Dasar Dan Menengah (2016). Indonesia.

Mukharomah, N. (2018). Program Sekolah Literasi Gratis (SLG) di STKIP PGRI Ponorogo. Jurnal Abdau : Jurnal Pendidikan Madrasah Ibtidaiyah, 1(2), 305-317.

PISA. (2016). PISA 2015 Results in Focus. OECD. https://doi.org/10.1787/9789264266490-en

Prenzel, M., Blum, W., \& Klieme, E. (2015). Assessing Mathematical Literacy. Assessing Mathematical Literacy: The PISA Experience. https://doi.org/10.1007/978-3-319-10121-7

Rahmawati. (2016). Analisis Hasil TIMSS 2015. 2016.

Setiana, N. (2016). Pengaruh Implementasi pendekatan tematik terhadap pemahaman konsep dan kreativitas siswa dalam pembelajaran ilmu pengetahuan sosial. EduHumaniora | Jurnal Pendidikan Dasar Kampus Cibiru, 3(1). https://doi.org/10.17509/eh.v3i1.2800

Suyitno, A. (2013). Mengembangkan kemampuan guru matematika dalam menyusun soal bermuatan literasi matematika sebagai wujud implementasi kurikulum 2013. AKSIOMA: Jurnal Matematika Dan 
JURNAL ANUGERAH. November 2019; I(1): 9 - 18

Pendidikan Matematika, 4(2). https://doi.org/DOI: http://dx.doi.org/10.26877/aks.v4i2/Septembe.552 Wardono, Waluya, S. B., Kartono, Mulyono, \& Mariani, S. (2018). Literasi matematika siswa SMP pada pembelajaran problem based learning realistik edmodo. Prisma, 1, 477-497. Retrieved from https://journal.unnes.ac.id/sju/index.php/prisma/article/view/20138 